\title{
ROLES OF $\mu$-OPIOID RECEPTORS IN DEVELOPMENT OF TOLERANCE TO DIISOPROPYLFLUOROPHOSPHATE (DFP)
}

\author{
Lu-Tai TIEN ${ }^{1}$, Lir-Wan FAN ${ }^{1}$, Tangeng MA ${ }^{1}$, Horace H. $\mathrm{LOH}^{2}$ and Ing Kang $\mathrm{HO}^{1}$ \\ ${ }^{1}$ Department of Pharmacology and Toxicology, University of Mississippi Medical Center, \\ Jackson, MS 39216, U.S.A. \\ ${ }^{2}$ Department of Pharmacology, University of Minnesota Medical School, \\ Minneapolis, MN 55455, U.S.A.
}

(Received September 17, 2004; Accepted December 13, 2004)

\begin{abstract}
Anatomical evidence indicates that cholinergic and opioidergic systems are co-localized and acting on the same neuron. However, the regulatory mechanisms between cholinergic and opioidergic system have not been well characterized. In the present study, the potential involvement of $\mu$-opioid receptors in mediating the changes of toxic signs and muscarinic receptor binding after administration of irreversible anti-acetylcholinesterase diisopropylfluorophosphate (DFP) was investigated. DFP $(1 \mathrm{mg} / \mathrm{kg} / \mathrm{day}$, subcutaneous injection, s.c.)-induced tremors and chewing movements were monitored during the 28-day treatment period in $\mu$-opioid receptor knockout and wild type mice. Autoradiographic studies of total, M1, and M2 muscarinic receptors were conducted using $\left[{ }^{3} \mathrm{H}\right]$-quinuclidinyl benzilate, $\left[{ }^{3} \mathrm{H}\right]$-pirenzepine, and $\left[{ }^{3} \mathrm{H}\right]$-AF-DX384 as ligands, respectively. DFP-induced tremors in both $\mu$-opioid receptor knockout and wild type mice showed tolerance development. However, DFP-induced tremors in $\mu$-opioid receptor knockout mice showed delayed tolerance development than that of DFP-treated wild type controls. DFPinduced chewing movements in both $\mu$-opioid receptor knockout and wild type mice failed to show development of tolerance after four weeks of treatment. M2 muscarinic receptor binding of DFP-treated $\mu$-opioid receptor knockout mice was significantly decreased than that of the DFP-treated wild type controls in the striatum, but not in the cortex and hippocampus. However, there were no significant differences in total and M1 muscarinic receptor binding between DFP-treated $\mu$-opioid receptor knockout and wild type mice in the cortex, striatum and hippocampus. These studies indicate that $\mu$-opioid receptors play an important role through the striatal M2 muscarinic receptors to regulate the development of tolerance to DFP-induced tremors.
\end{abstract}

KEY WORDS: Diisopropylfluorophosphate, $\mu$-Opioid receptors, M1 and M2 muscarinic receptors, Autoradiography

\section{INTRODUCTION}

Muscarinic receptors are the predominant cholinergic receptors in the central nervous system and play important roles in learning and memory (Hozumi et al., 2003; van der Zee and Luiten, 1999), control of movement (Shapovalova, 2002), and central nociception (Wess et al., 2003). The cholinergic cells serve as interneurons: short-axoned cells that participate in local circuits in striatal brain area (Feldman et al., 1997; Wainer et al., 1984; Woolf, 1991). These cholinergic cells play an important role in function of the extrapyramidal motor system such as tremors (Bymaster et al., 2001; Cousins et al., 1999). It is well known that there are interactions between cholinergic system and other neurotransmitter systems such as dopaminergic (Lim et al., 1988; Pisani et al., 2000) and GABAergic systems (Harsing and Zigmond, 1998; Sivam et al., 1983). However, the interactions between cholinergic system and $\mu$-opioid receptor, one of the most widely distributed opioid receptors, are rarely studied.

It has been reported that activation of $\mu$-opioid

Correspondence: Ing Kang $\mathrm{HO}$ 
receptor causes inhibition of acetylcholine release in the striatum (Taguchi et al., 1993), cortex (Lapchak et al., 1989) and hippocampus (Gazyakan et al., 2000; Sakai et al., 2002) in the presynaptic cholinergic system. For example, fentanyl, a synthetic $\mu$-opioid receptor agonist, significantly decreased the acetylcholine release from the rat hippocampus. Naloxone, an $\mu$-opioid receptor antagonist, antagonized the inhibitory effect of fentanyl on acetylcholine release in the hippocampus (Sakai et al., 2002). However, it has been reported that activation of $\mu$-opioid receptor causes enhancement of acetylcholine release in several brain areas such as the striatum (Green et al., 1976), cortex (Feuerstein et al., 1996), hippocampus (Imperato et al., 1996), and rostral ventrolateral medulla (Taguchi et al., 1999). For example, morphine increased levels of acetylcholine in mouse striatum in a dose-dependent manner. Naloxone blocked this effect of morphine in the striatum (Green et al., 1976). In addition, cholinergic receptor agonists inhibit the withdrawal signs induced by morphine in animals (Buccafusco et al., 2000; Padmanabha Phillai et al., 1982). For example, the central acting cholinergic receptor agonist, arecoline, suppressed withdrawal body shakes (wet dog shakes) occurred in morphine withdrawal rat (Buccafusco et al., 2000). It seems that the $\mu$-opioid receptors play an important role in regulating the central cholinergic system. However, the interaction between $\mu$-opioidergic and cholinergic systems is not well understood.

DFP, an irreversible acetylcholinesterase inhibitor, produces peripheral and central cholinergic overstimulation to cause excessive physiological actions such as salivation, lacrimation, miosis, weakness, and tremors (Gordon, 1993; Mattio et al., 1984; Smolen et $a l .$, 1985). Repeated exposures to cholinesterase inhibitors can result in adaptive changes that significantly reduce toxicity in the presence of continued decrease in acetylcholinesterase activity (Russell and Overstreet, 1987). For example, chronic administration of low dose of DFP results in tolerance to the behavioral and physiological effects in rats (Dulaney et al., 1989; Lim et al., 1983; Overstreet, 1973; Russell et al., 1969; Glow et al., 1966). This study was designed to investigate whether the $\mu$-opioid receptors are involved in changes of central muscarinic receptors and the regulations of DFP-induced toxic signs during the development of tolerance to DFP. The most abundant central cholinergic distributed areas and related motor behaviors were studied. These aims were carried out by monitoring behaviors, determining acetylcholinesterase activity, and measuring central muscarinic receptor binding in $\mu$-opioid receptor knockout and wild type mice after receiving chronically repeated administration of DFP or saline.

\section{MATERIALS AND METHODS}

\section{Animals}

$\mu$-Opioid receptor knockout mice used in this experiment were developed by Loh et al. (1998) and maintained on a 1:1 hybrid genetic background (C57/ BL6 and 129 /Ola). Both $\mu$-opioid receptor knockout and wild type mice were maintained in an animal room on a 12-hr light/dark cycle and at constant temperature $\left(22 \pm 2^{\circ} \mathrm{C}\right)$. All procedures for animal care and breeding were conducted in accordance with the NIH Guide for the Care and Use of Laboratory Animals and were approved by the University of Mississippi Medical Center Animal Care and Use Committee.

\section{Drug preparation}

DFP was purchased from Sigma chemical company (St. Louis, MO, USA). Stock solution of DFP (10 $\mathrm{mg} / \mathrm{ml}$ ) was prepared in distilled water and kept frozen at $-80^{\circ} \mathrm{C}$. Freshly prepared solution of DFP in saline was used. Mice were placed individually in a plastic cage and acclimated for at least $30 \mathrm{~min}$ before treatment. All injections were done between 9:00 to 11:00 in the morning according to the previously reported studies (Bushnell et al., 1991; Prendergast et al., 1997).

\section{Drug administration and behavioral observations}

Male $\mu$-opioid receptor knockout and wild type mice between 8 to 12 weeks old were used in these experiments. Respective mice were randomly divided into groups of 8 mice each. Mice were injected with a single daily dose of $1 \mathrm{mg} / \mathrm{kg}$ of DFP (s.c.) for 28 days and the control animals received an equivalent volume of saline. The method and definition of toxic signs measured were according to previous studies from our laboratory (Fernando et al., 1984; Lim et al., 1987). The toxic signs, chewing movements (without biting or gnawing of objects) and tremors, were observed 10 min after the administration of DFP or saline. They were separately scored on each mouse for a duration of $5 \mathrm{~min}$ and repeated at $10 \mathrm{~min}$ intervals. The scoring scale utilized was: $0=$ none, $1=$ slight, $2=$ moderate, or $3=$ severe, for the chewing-movements. The score for tremors was: $0=$ none, $1=$ distinct slow tremor of head, 2 = fast tremor (high frequency vibrations) of head, trunk or limbs, or $3=$ intense fast tremor 
DFP in $\mu$-opioid receptor knockout mice.

(Fernando et al., 1984; Lim et al., 1987; Tien et al., 2004a). DFP-induced behaviors were observed for a period of $30 \mathrm{~min}$ per day in $\mu$-opioid receptor knockout and wild type mice.

\section{Brain sample preparations}

Mice were sacrificed by decapitation and the brains were removed from the skull and immediately frozen in liquid nitrogen. Coronal sections of $20 \mu \mathrm{m}$ thickness were cut in a microtome cryostat (Leica $\mathrm{CM} 3050 \mathrm{~S}$, Germany) at $-20^{\circ} \mathrm{C}$ and brain areas were collected according to the mouse atlas of Franklin and Paxinos (1997). The brain sections were thaw-mounted on a gelatin-coated slide (Allegiance Healthcare Corporation, IL, USA) and stored at $-80^{\circ} \mathrm{C}$ until used.

\section{Acetylcholinesterase activity by histochemistry assay}

Acetylcholinesterase activity was measured by the method as described previously (Ma et al., 2001; Tien et al., 2004a, b). Prior to incubation, brain sections mounted on the slides were brought to room temperature and blown dry under air for $45 \mathrm{~min}$. The dried slices were incubated in a $50 \mathrm{mM}$ acetate buffer $(\mathrm{pH}$ 5.0) containing $2 \mathrm{mM}$ acetylthiocholine iodide (substrate), $2 \mathrm{mM}$ copper sulfate, and $10 \mathrm{mM}$ glycine for 45 min at $37^{\circ} \mathrm{C}$. Tetraisopropylpyrophosphoramide was present in the medium at a concentration of $20 \mu \mathrm{M}$ to inhibit nonspecific cholinesterase. After incubation, the slides were rinsed by $50 \mathrm{mM}$ acetate buffer $(\mathrm{pH}$ 5.0) for 5 times ( 45 seconds each). Then, slides were transferred into a $1.25 \%$ sodium sulfide solution for 1 min and rinsed by $50 \mathrm{mM}$ acetate buffer (pH 5.0) for 5 times (45 seconds each). Then, slides were transfer to a $1 \%$ silver nitrate solution in distilled water for $1 \mathrm{~min}$ and rinsed by $50 \mathrm{mM}$ acetate buffer ( $\mathrm{pH} 5.0$ ) for 5 times (45 seconds each time). Finally, the sections were dipped quickly in cold distilled water and blown dry under air at room temperature for at least $30 \mathrm{~min}$ and stored at $25^{\circ} \mathrm{C}$ until image analysis. Stained brain sections on the slides were scanned and analyzed quantitatively with a Molecular Dynamics personal densitometer (Sunnyvale, CA, USA) as described previously (Ma et al., 2001; Tien et al., 2004a, b). Optical densities (OD) were used to express staining intensities.

\section{Radioisotopes}

$\left[{ }^{3} \mathrm{H}\right]$-Quinuclidinyl benzilate (QNB, 42.0 Ci/ mmol), $\left[{ }^{3} \mathrm{H}\right]$-pirenzepine (PZ, 79.0 Ci/mmol) and $\left[{ }^{3} \mathrm{H}\right]-$ AF-DX384 $(100 \mathrm{Ci} / \mathrm{mmol})$ were purchased from New England Nuclear (Boston, MA, USA).

\section{Autoradiography of muscarinic receptors}

$\left[{ }^{3} \mathrm{H}\right]-\mathrm{QNB}$ binding was measured by the method of Schwab et al. (1992) with modifications. The brain sections were thawed and dried at room temperature, then incubated with cold $50 \mathrm{mM}$ phosphate buffer $(\mathrm{pH}$ 7.4) for $30 \mathrm{~min}$. These sections were dried with cool air and incubated with the concentration of $1 \mathrm{nM}\left[{ }^{3} \mathrm{H}\right]-$ QNB for $3 \mathrm{hr}$ at room temperature. After incubation, these sections were washed with cold buffer $\left(4^{\circ} \mathrm{C}\right)$ for 5 min twice then rinsed with cold distilled water for 5 sec. The wet sections were immediately dried using cool air stream and desiccated overnight. Non-specific binding was determined in the presence of $40 \mu \mathrm{M}$ atropine in the incubation system.

The binding of $\left[{ }^{3} \mathrm{H}\right]-\mathrm{PZ}$ and $\left[{ }^{3} \mathrm{H}\right]-\mathrm{AF}-\mathrm{DX} 384$ was performed according to Schwab et al. (1992) and Gattu et al. (1997), respectively. The brain sections were thawed and dried at room temperature, then incubated with cold $10 \mathrm{mM}$ phosphate buffer ( $\mathrm{pH}$ 7.4) for $30 \mathrm{~min}$. These sections were dried with cool air and incubated with the concentration of $9 \mathrm{nM}\left[{ }^{3} \mathrm{H}\right]-\mathrm{PZ}$ or $5 \mathrm{nM}\left[{ }^{3} \mathrm{H}\right]-$ AF-DX384 for $1 \mathrm{hr}$ at room temperature. After incubation, these sections were washed with cold buffer $\left(4^{\circ} \mathrm{C}\right)$ for 5 min twice then rinsed with cold distilled water for $5 \mathrm{sec}$. The wet sections were immediately dried using cool air stream and desiccated overnight. Non-specific binding was determined in the presence of $40 \mu \mathrm{M}$ atropine.

The slides were placed in X-ray cassettes with calibration standards and juxtaposed to Cyclone ${ }^{\mathrm{TM}}$ Storage Phosphor screen (Packard Instrument Company, Inc., Meriden, CT, USA). After 1 week of exposure at $4{ }^{\circ} \mathrm{C}$ for $\left[{ }^{3} \mathrm{H}\right]-\mathrm{QNB}$ and $\left[{ }^{3} \mathrm{H}\right]-\mathrm{PZ}$ and 10 days of exposure at $4^{\circ} \mathrm{C}$ for $\left[{ }^{3} \mathrm{H}\right]-\mathrm{AF}-\mathrm{DX} 384$, the images on screens were detected by a Packard Cyclone ${ }^{\mathrm{TM}}$ Storage Phosphor System and analyzed by the analysis program, ImageQuant 3.3 (Molecular Dynamics).

\section{Statistical analysis}

Data were expressed as mean \pm standard errors of the mean (S.E.M.). For behavioral experiments, statistical analysis was done by Kruskal-Wallis ANOVA on Ranks followed by a post-hoc Student-Newman-Keuls multiple comparison test (Tien et al., 2004a). A difference was considered significant at $\mathrm{p}<0.05$. For acetylcholinesterase activity and receptor binding experiments, statistical analysis was done by one-way ANOVA followed by a post-hoc Student-NewmanKeuls multiple comparison test. A difference was considered significant at $\mathrm{p}<0.05$. 


\section{RESULTS}

\section{Effects of DFP on animal body weight and behav- iors}

The percentage of body weight changes in salinetreated wild type mice was increased slowly and steadily during the treatment. The percentage of body weight changes in saline-treated $\mu$-opioid receptor knockout was decreased slowly at the first two weeks and recovered during the later part of the treatment period. Meanwhile, the percentage of body weight changes in DFP-treated $\mu$-opioid receptor knockout and wild type mice was decreased at the first two weeks and recovered slowly after two weeks of the treatment. The percentage of body weight changes in saline-treated wild type mice was significantly higher than that of the other three treated groups. There was no significant difference in percentage of body weight changes among DFP-treated wild type, saline- and DFP-treated $\mu$-opioid receptor knockout mice (Fig. 1).

The DFP-induced chewing movements in $\mu$-opioid receptor knockout and wild type mice showed gradual increase than that of saline-treated respective controls in the first week. The DFP-induced chewing movements in $\mu$-opioid receptor knockout mice were significantly higher than that of the wild type mice after the sixth day of the treatments. In addition, the DFP-induced chewing movements in both $\mu$-opioid receptor knockout and wild type mice failed to show development of tolerance after four weeks of treatment (Fig. 2).

Both saline-treated $\mu$-opioid receptor knockout and wild type mice did not show any obvious sign of tremors during four-week treatment period. In the wild type mice that received DFP $(1 \mathrm{mg} / \mathrm{kg} / \mathrm{day}$, s.c.), tremors occurred at fifth day after the treatment and disappeared after the seventeenth treatment. On the other hand, the tremors were much severe in the $\mu$-opioid receptor knockout mice when they received the same dose of DFP. The peak reached between fifth to ninth days and gradually subsided. However, the incidence of tremors was still presence during four weeks of treatment. Although tolerance to DFP-induced tremors developed in both $\mu$-opioid receptor knockout and wild type mice, it is much more obvious in the case of wild type mice (Fig. 3).

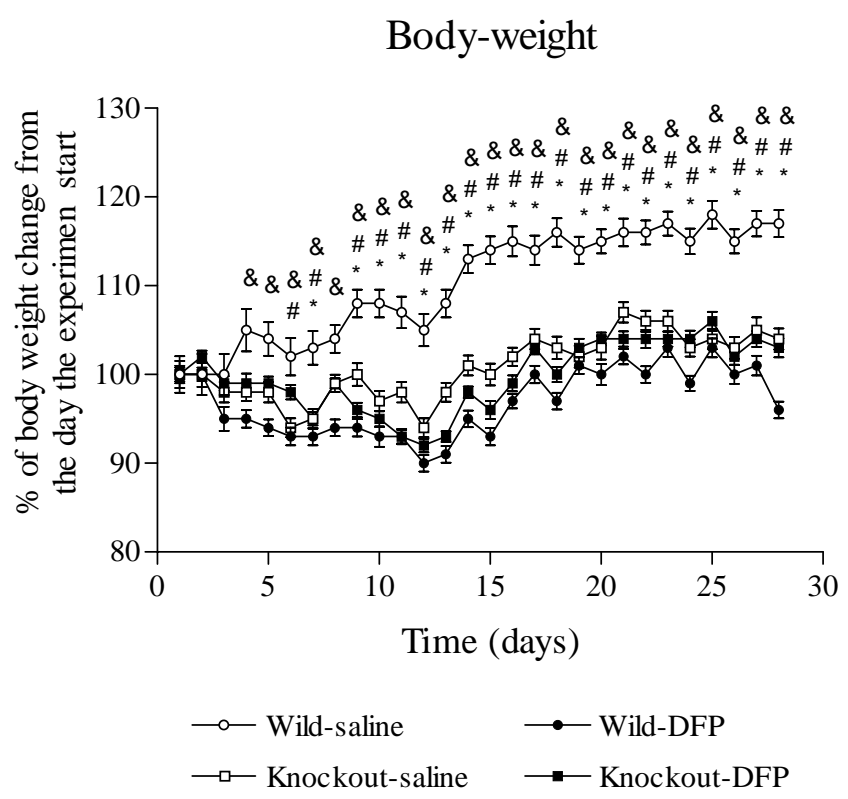

Fig. 1. Effects of DFP (1 mg/kg/day, s.c.) on body weight in $\mu$ opioid receptor knockout and wild type mice. The results represent mean \pm S.E.M. from 8 mice in each group. ${ }^{\#} \mathrm{p}<$ 0.05 compared with the saline-treated $\mu$-opioid receptor knockout mice. ${ }^{*} \mathrm{p}<0.05$ compared with the DFP-treated wild type mice. ${ }^{\&} \mathrm{p}<0.05$ compared with the DFP-treated $\mu$-opioid receptor knockout mice. 
DFP in $\mu$-opioid receptor knockout mice.

Effects of DFP on acetylcholinesterase activity and muscarinic receptor binding

Acetylcholinesterase activity was distributed in the rat brain with following order of staining intensity: striatum > CA1-3 pyramidal layer and dentate gyrus granule layer of hippocampal formation > cerebral cortex (Ma et al., 2001). The acetylcholinesterase activity in striatal caudate-putamen and nucleus accumbens of saline-treated $\mu$-opioid receptor knockout mice was significantly higher than that of the saline-treated wild type mice (Table 1). DFP administration inhibited acetylcholinesterase activity in both $\mu$-opioid receptor knockout and wild type mice (Table 1). There was no significant difference in acetylcholinesterase activity in the striatum and hippocampus between DFP-treated $\mu$ opioid receptor knockout and wild type mice (Table 1).

In order to investigate the role of $\mu$-opioid receptors during the development of tolerance to DFP, the studies on acetylcholinesterase activity and binding of muscarinic receptors have been performed at the seventh day (at the peak of DFP-induced tremors) and the twenty-eighth day (tolerance developed in DFP-treated wild type mice) treatment in this study.

Total and M1 muscarinic receptor binding of

\section{Chewing movements}

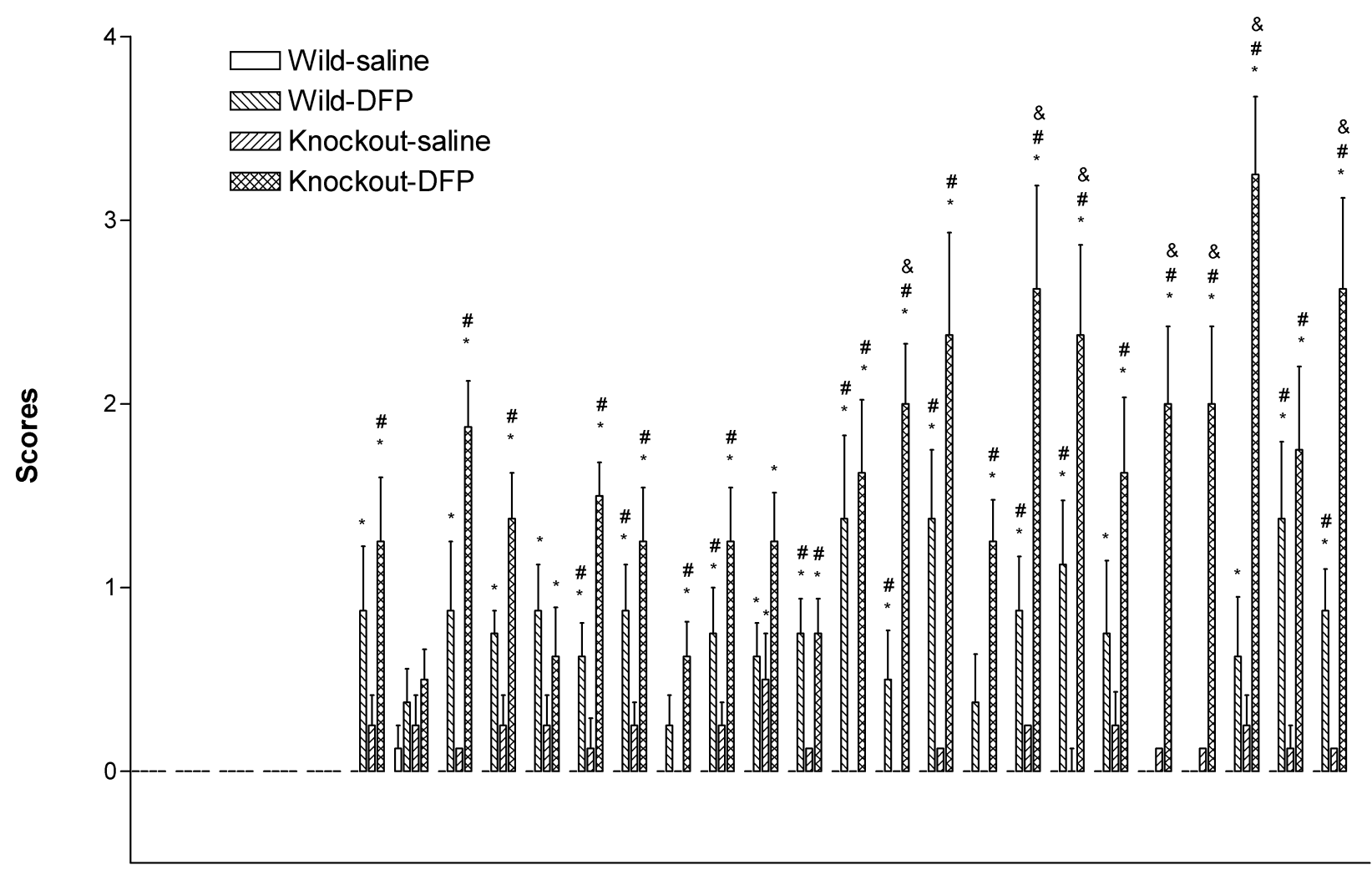

$\begin{array}{llllllllllllllllllllllllllll}1 & 2 & 3 & 4 & 5 & 6 & 7 & 8 & 9 & 10 & 11 & 12 & 13 & 14 & 15 & 16 & 17 & 18 & 19 & 20 & 21 & 22 & 23 & 24 & 25 & 26 & 27 & 28\end{array}$

\section{Time (days)}

Fig. 2. Chewing movements induced by DFP ( $1 \mathrm{mg} / \mathrm{kg} /$ day, s.c. $)$ in $\mu$-opioid receptor knockout and wild type mice. The results represent mean \pm S.E.M. from 8 mice in each group. Statistical analysis was performed using Mann-Whitney Rank Sum test. * $p<$ 0.05 compared with the saline-treated wild type mice. ${ }^{\#} \mathrm{p}<0.05$ compared with the saline-treated $\mu$-opioid receptor knockout mice. ${ }^{\&} \mathrm{p}<0.05$ compared with DFP-treated wild type mice. 
saline-treated $\mu$-opioid receptor knockout mice was not significantly different from that of the saline-treated wild type controls in the cortex, striatum and hippocampus (Tables 2, 3, 5 and 6). However, M2 muscarinic receptor binding in the saline-treated $\mu$-opioid receptor knockout mice was significantly less than that of the wild type controls in striatal caudate-putamen and nucleus accumbens, but not in the cortex and hippocampus (Tables 4 and 7). In mice receiving the administration of DFP for 7 days, total and M1 muscarinic receptor binding of DFP-treated wild type mice was significantly decreased than that of the saline-treated controls in the cortex, striatum and hippocampus (Tables 2 and 3). M2 muscarinic receptor binding of DFP-treated wild type mice was significantly decreased than that of the saline-treated controls in the striatum, but not in the cortex and hippocampus (Table 4). M2 muscarinic receptor binding of DFP-treated $\mu$ opioid receptor knockout mice was significantly decreased than that of the DFP-treated wild type mice in the striatum, but not in the cortex and hippocampus (Table 4).

After the mice receiving administration of DFP for 28 days, the total, M1 and M2 muscarinic receptor

\section{Tremors}

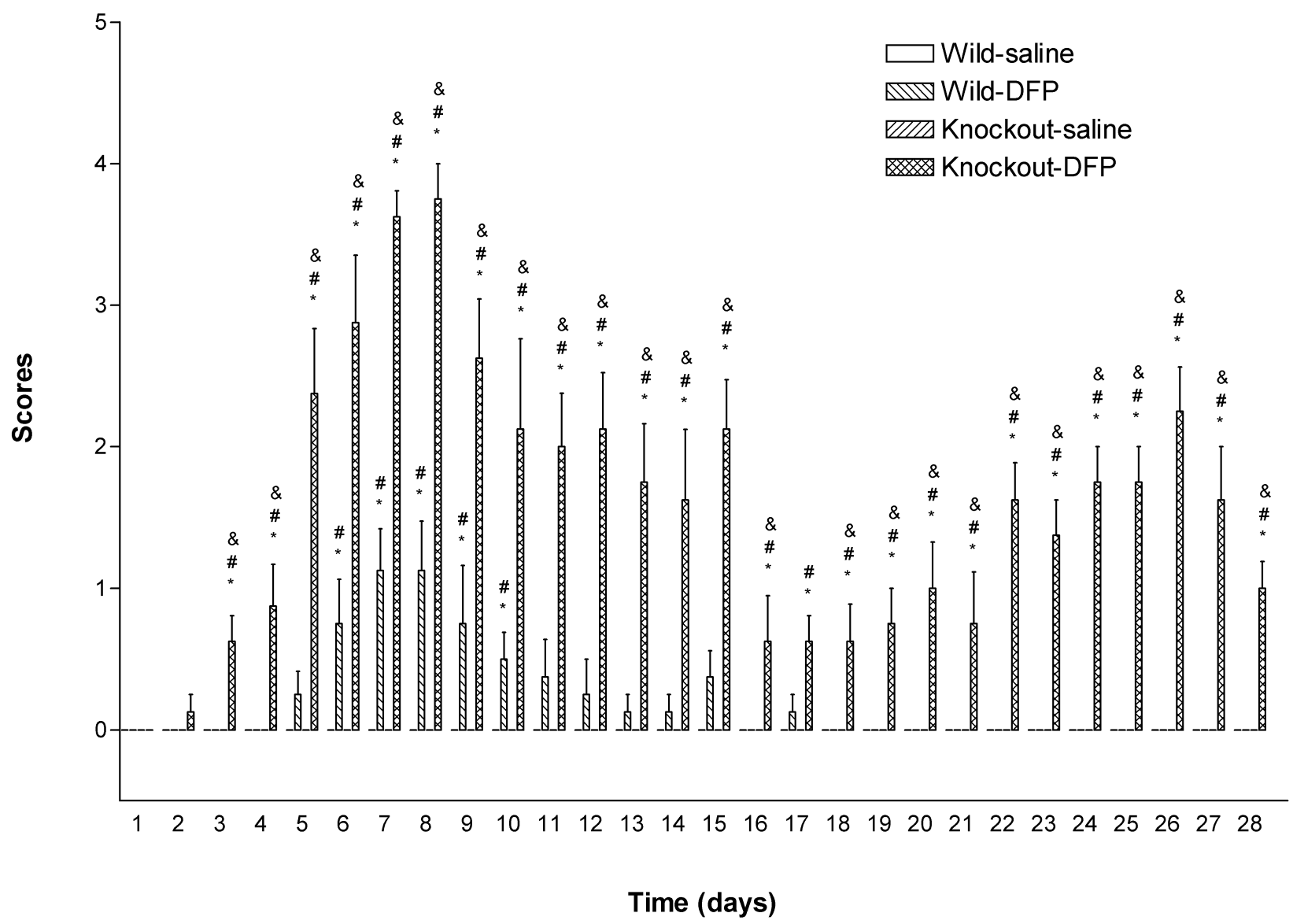

Fig. 3. Tremors induced by DFP ( $1 \mathrm{mg} / \mathrm{kg} / \mathrm{day}$, s.c.) in $\mu$-opioid receptor knockout and wild type mice. The results represent mean \pm S.E.M. from 8 mice in each group. Statistical analysis was performed using Mann-Whitney Rank Sum test. * p $<0.05$ compared with the saline-treated wild type mice. ${ }^{\#} \mathrm{p}<0.05$ compared with the saline-treated $\mu$-opioid receptor knockout mice. ${ }^{\&} \mathrm{p}<0.05$ compared with DFP-treated wild type mice. 
DFP in $\mu$-opioid receptor knockout mice.

binding of DFP-treated wild type mice was significantly decreased than that of the saline-treated controls in the cortex, striatum and hippocampus (Tables 5-7). M2 muscarinic receptor binding of DFP-treated $\mu$-opioid receptor knockout mice was significantly decreased than that of the DFP-treated wild type mice in the striatum, but not in the cortex and hippocampus (Table 7). However, there was no significant difference in the total and M1 muscarinic receptor binding in the cortex and hippocampus between DFP-treated $\mu$-opioid receptor knockout and wild type mice (Tables 5 and $6)$.

\section{DISCUSSION}

It has been reported that rats receiving $1 \mathrm{mg} / \mathrm{kg}$ of DFP the first day followed by three intervals of 22 days with doses of $0.5 \mathrm{mg} / \mathrm{kg}$ maintained brain acetylcholinesterase activity at approximately $30 \%$ of the control levels (Glow et al., 1966; Russell et al., 1969, 1975; Overstreet, 1973). A previous study from our laboratory indicated that DFP, $1 \mathrm{mg} / \mathrm{kg}$, daily for 14 days maintained acetylcholinesterase activity at approximately $33 \%$ of control activity (Sivam et al., 1983). Similar results in the present study show that acetylcholinesterase activity was maintained at approximately $32 \%$ of control levels following subacute administration of DFP in mice. This study indicated that DFP, $1 \mathrm{mg} / \mathrm{kg}$, daily for 7 days maintained acetylcholinesterase activity $42.5 \%$ and $37.7 \%$ of the control levels in the caudate-putamen of wild type and $\mu$-opioid receptor knockout mice, respectively. DFP, 1 $\mathrm{mg} / \mathrm{kg}$, daily for 7 days maintained acetylcholinesterase activity $40.3 \%$ and $37.9 \%$ of the control levels in the nucleus accumbens of wild type and $\mu$-opioid receptor knockout mice, respectively. DFP, $1 \mathrm{mg} / \mathrm{kg}$, daily for 28 days maintained acetylcholinesterase activity $45 \%$ and $48.8 \%$ of the control levels in the caudate-putamen of wild type and $\mu$-opioid receptor knockout mice, respectively. The levels in the nucleus accumbens were $40.3 \%$ and $37.9 \%$ in wild type and $\mu$ opioid receptor knockout mice, respectively. There was no significant difference in maintained acetylcholinesterase activity of the caudate-putamen and nucleus accumbens in the two genotypes of mice after administration of DFP for 7 or 28 days.

DFP treatment-induced tremors and chewing movements that were greater in $\mu$-opioid receptor knockout and wild type mice than that of saline treated respective controls during the first week of treatment. These responses are hypothesized to be related to increased cholinergic neuronal activity. However, DFP-induced chewing movements in $\mu$-opioid receptor knockout mice were not significantly higher than that of the wild type mice until three weeks after the treatments. These results may be associated with the regulation of behaviors by specific muscarinic receptor subtypes. For example, tremors are related to M2 muscarinic receptors (Gomeza et al., 2001) and chewing movements are related to M4 muscarinic receptors (Stewart et al., 1989). There was compensatory downregulation of M2 muscarinic receptors in $\mu$-opioid

Table 1. Change in acetylcholinesterase activity in coronal brain sections of the wild type and $\mu$-opioid receptor knockout mice.

\begin{tabular}{|c|c|c|c|c|c|c|}
\hline \multirow[b]{3}{*}{ Brain regions } & \multicolumn{6}{|c|}{ Intensity of AChE staining (OD) } \\
\hline & \multicolumn{3}{|c|}{ Wild type } & \multicolumn{3}{|c|}{$\mu-$ Knockout } \\
\hline & Saline & DFP (7 days) & DFP (28 days) & Saline & DFP (7 days) & DFP (28 days) \\
\hline \multicolumn{7}{|l|}{ Striatal complex } \\
\hline Caudate-putamen & $0.40 \pm 0.01$ & $0.17 \pm 0.01 *$ & $0.18 \pm 0.01 *$ & $0.45 \pm 0.01 *$ & $0.17 \pm 0.01^{\#}$ & $0.22 \pm 0.01^{\#}$ \\
\hline Nucleus accumbens & $0.52 \pm 0.01$ & $0.21 \pm 0.01 *$ & $0.21 \pm 0.01 *$ & $0.58 \pm 0.03 *$ & $0.22 \pm 0.01^{\#}$ & $0.22 \pm 0.01^{\#}$ \\
\hline \multicolumn{7}{|c|}{ Hippocampal formation } \\
\hline CA1 & $0.12 \pm 0.001$ & $0.08 \pm 0.002$ & $0.09 \pm 0.002$ & $0.13 \pm 0.001$ & $0.08 \pm 0.002$ & $0.09 \pm 0.002$ \\
\hline CA2 & $0.09 \pm 0.003$ & $0.08 \pm 0.001$ & $0.08 \pm 0.001$ & $0.10 \pm 0.001$ & $0.09 \pm 0.001$ & $0.08 \pm 0.001$ \\
\hline CA3 & $0.09 \pm 0.002$ & $0.07 \pm 0.002$ & $0.07 \pm 0.001$ & $0.09 \pm 0.001$ & $0.08 \pm 0.001$ & $0.08 \pm 0.001$ \\
\hline Dentate gyrus & $0.10 \pm 0.004$ & $0.08 \pm 0.001$ & $0.07 \pm 0.002$ & $0.10 \pm 0.001$ & $0.07 \pm 0.001$ & $0.08 \pm 0.001$ \\
\hline
\end{tabular}

Values are represented as means \pm S.E.M. in each group. Statistical analysis was performed using one-way ANOVA followed by Student-Newman-Keuls test. ( ${ }^{*} \mathrm{p}<0.05$ compared with saline-treated wild type mice, ${ }^{*} \mathrm{p}<0.05$ compared with saline-treated $\mu$ opioid receptor knockout mice) 
receptor knockout mice that was greater than that of the wild type controls. Thus, DFP-induced tremors in $\mu$-opioid receptor knockout mice were significantly increased than that of the wild type mice. It is hypothesized that there was no significant difference in M4 muscarinic receptors between $\mu$-opioid receptor knockout and wild type mice. Thus, DFP-induced chewing movements in $\mu$-opioid receptor knockout mice were not significantly different from that of the wild type mice. However, it is not certain for change of M4 muscarinic receptors in $\mu$-opioid receptor knockout mice due to the limitation of hotligand.
The two genotypes of mice showed development of tolerance to DFP-induced tremors but failed to develop tolerance to DFP-induced chewing movements during the four weeks treatment period. Previous evidence indicated development of tolerance to DFP-induced tremors but not to chewing movements after four weeks of treatment in rats (Fernando et al., 1984). Our results indicate that the $\mu$-opioid receptors play an important role to regulate the development of tolerance to DFP-induced tremors but not to DFPinduced chewing movements. It has been reported that the nucleus accumbens is involved in the production of

Table 2. Effects of repeated administration (7 days) of DFP on binding of $\left[{ }^{3} \mathrm{H}\right]$-quinuclidinyl benzilate to muscarinic cholinergic receptors in coronal brain sections of the wild type and $\mu$-opioid receptor knockout mice.

\begin{tabular}{|c|c|c|c|c|}
\hline \multirow{3}{*}{ Brain region } & \multicolumn{4}{|c|}{$\left[{ }^{3} \mathrm{H}\right]-\mathrm{QNB}$ binding (nCi/mg tissue) } \\
\hline & \multicolumn{2}{|c|}{ Wild type } & \multicolumn{2}{|c|}{$\mu$-Knockout } \\
\hline & Saline & $\begin{array}{c}\text { DFP } \\
(1 \mathrm{mg} / \mathrm{kg}, 7 \text { days })\end{array}$ & Saline & $\begin{array}{c}\text { DFP } \\
(1 \mathrm{mg} / \mathrm{kg}, 7 \text { days })\end{array}$ \\
\hline \multicolumn{5}{|l|}{ Striatal complex } \\
\hline Caudate-putamen & $21.3 \pm 0.9$ & $15.4 \pm 0.8 *$ & $17.8 \pm 0.5$ & $13.1 \pm 0.5^{\#}$ \\
\hline Nucleus accumbens & $20.4 \pm 0.7$ & $15.6 \pm 0.8 *$ & $17.5 \pm 0.5$ & $14.6 \pm 0.6^{\#}$ \\
\hline \multicolumn{5}{|l|}{ Cortex } \\
\hline Retrosplenial agranular, Layer I & $14.8 \pm 0.7$ & $11.3 \pm 0.6 *$ & $14.8 \pm 0.6$ & $11.1 \pm 0.7^{\#}$ \\
\hline Retrosplenial agranular, Layer III & $14.1 \pm 0.6$ & $10.2 \pm 0.9 *$ & $14.1 \pm 0.5$ & $10.6 \pm 0.4^{\#}$ \\
\hline Retrosplenial agranular, Layer V & $12.8 \pm 0.7$ & $9.6 \pm 0.6 *$ & $11.9 \pm 0.5$ & $9.2 \pm 0.4^{\#}$ \\
\hline Primary somatosensory cortex, Layer I & $16.7 \pm 0.6$ & $12.4 \pm 0.5 *$ & $16.4 \pm 0.8$ & $12.5 \pm 0.6^{\#}$ \\
\hline Primary somatosensory cortex, Layer III & $11.2 \pm 1.5$ & $8.7 \pm 0.4 *$ & $11.4 \pm 0.5$ & $8.3 \pm 0.4^{\#}$ \\
\hline Primary somatosensory cortex, Layer V & $11.8 \pm 0.5$ & $8.8 \pm 0.8 *$ & $11.8 \pm 0.4$ & $8.7 \pm 0.1{ }^{\#}$ \\
\hline Ectorhinal cortex, Layer I & $12.6 \pm 0.6$ & $9.8 \pm 0.7 *$ & $12.1 \pm 0.3$ & $9.0 \pm 0.3^{\#}$ \\
\hline Ectorhinal cortex, Layer III & $10.4 \pm 0.4$ & $8.7 \pm 0.6 *$ & $10.5 \pm 0.5$ & $8.2 \pm 0.3^{\#}$ \\
\hline Ectorhinal cortex, Layer V & $10.8 \pm 0.4$ & $8.5 \pm 0.5 *$ & $10.9 \pm 0.4$ & $8.3 \pm 0.4^{\#}$ \\
\hline Lateral entorhinal, Layer I & $12.2 \pm 0.6$ & $9.4 \pm 0.4 *$ & $12.2 \pm 0.6$ & $9.0 \pm 0.4^{\#}$ \\
\hline Lateral entorhinal, Layer III & $10.5 \pm 0.4$ & $7.3 \pm 0.5 *$ & $10.3 \pm 0.5$ & $7.5 \pm 0.3^{\#}$ \\
\hline Lateral entorhinal, Layer V & $11.2 \pm 0.2$ & $8.1 \pm 0.4 *$ & $11.3 \pm 0.5$ & $8.3 \pm 0.3^{\#}$ \\
\hline \multicolumn{5}{|l|}{ Hippocampal formation } \\
\hline CA1 & $13.6 \pm 0.8$ & $9.8 \pm 0.7 *$ & $12.1 \pm 0.5$ & $10.1 \pm 0.4^{\#}$ \\
\hline CA2 & $11.4 \pm 0.6$ & $9.0 \pm 0.7 *$ & $11.0 \pm 0.3$ & $8.5 \pm 0.5^{\#}$ \\
\hline CA3 & $13.5 \pm 0.3$ & $9.0 \pm 0.4 *$ & $12.2 \pm 0.5$ & $9.2 \pm 0.3^{\#}$ \\
\hline Dentate gyrus & $14.3 \pm 0.5$ & $12.1 \pm 1.0 *$ & $14.1 \pm 1.0$ & $12.0 \pm 0.4^{\#}$ \\
\hline
\end{tabular}

Values are represented as means \pm S.E.M. from 5 individual mice in each group. Statistical analysis was performed using one-way ANOVA followed by Student-Newman-Keuls test. (* $\mathrm{p}<0.05$ was compared with the saline-treated wild type mice; ${ }^{\#} \mathrm{p}<0.05$ was compared with the saline-treated $\mu$-opioid receptor knockout mice) 
DFP in $\mu$-opioid receptor knockout mice.

chewing movements (Kelley et al., 1989; Salamone et $a l .$, 1990). The nucleus accumbens of the ventral striatum is involved in motivational behavior such as reinforcement-related incentive learning (Robbins and Everitt, 1996; Kelley, 1999), while the nonlimbic dorsal striatum (caudate-putamen) is primarily involved in somatomotor functioning (Alexander and Crutcher, 1990; Graybiel et al., 1994). The nucleus accumbens contains small populations of $\gamma$-aminobutyric acid (GABA)-containing and cholinergic interneurons, in addition to a large number of efferent and recurrent projecting GABAergic medium spiny neurons (Smith and Bolam, 1990; Di Chiara et al., 1994). In addition to being regulated by intrinsic GABAergic inputs, the activity of the nucleus accumbens output neurons is also controlled by glutamatergic inputs arising from the prefrontal cortex, hippocampus and amygdala, and by dopaminergic input from the ventral tegmental area (Groenewegen et al., 1996; Kelley, 1999). Evidence has been presented that injections of dopamine agonists into the nucleus accumbens are capable of inducing oral activity as well (Koene et al., 1993; Koshikawa et al., 1990). The regulation of chewing movements is not clearly understood because it may be associated

Table 3. Effects of repeated administration (7 days) of DFP on binding of $\left[{ }^{3} \mathrm{H}\right]$-pirenzepine to $\mathrm{M} 1$ muscarinic cholinergic receptors in coronal brain sections of the wild type and $\mu$-opioid receptor knockout mice.

\begin{tabular}{|c|c|c|c|c|}
\hline \multirow{3}{*}{ Brain region } & \multicolumn{4}{|c|}{$\left[{ }^{3} \mathrm{H}\right]-\mathrm{PZ}$ binding (nCi/mg tissue) } \\
\hline & \multicolumn{2}{|c|}{ Wild type } & \multicolumn{2}{|c|}{$\mu$-Knockout } \\
\hline & Saline & $\begin{array}{c}\text { DFP } \\
(1 \mathrm{mg} / \mathrm{kg}, 7 \text { days })\end{array}$ & Saline & $\begin{array}{c}\text { DFP } \\
(1 \mathrm{mg} / \mathrm{kg}, 7 \text { days })\end{array}$ \\
\hline \multicolumn{5}{|l|}{ Striatal complex } \\
\hline Caudate-putamen & $23.6 \pm 1.0$ & $18.7 \pm 0.3 *$ & $23.5 \pm 1.2$ & $16.7 \pm 1.3^{\#}$ \\
\hline Nucleus accumbens & $22.6 \pm 0.7$ & $19.6 \pm 0.5 *$ & $22.7 \pm 0.6$ & $19.9 \pm 1.0^{\#}$ \\
\hline \multicolumn{5}{|l|}{ Cortex } \\
\hline Retrosplenial agranular, Layer I & $12.7 \pm 0.2$ & $9.5 \pm 0.5 *$ & $11.7 \pm 0.5$ & $9.8 \pm 0.2^{\#}$ \\
\hline Retrosplenial agranular, Layer III & $10.7 \pm 0.3$ & $8.9 \pm 0.2 *$ & $10.9 \pm 0.4$ & $8.5 \pm 0.4^{\#}$ \\
\hline Retrosplenial agranular, Layer V & $10.2 \pm 0.3$ & $8.6 \pm 0.1 *$ & $11.0 \pm 0.3$ & $8.5 \pm 0.4^{\#}$ \\
\hline Primary somatosensory cortex, Layer I & $21.4 \pm 1.2$ & $17.8 \pm 0.7 *$ & $22.5 \pm 1.0$ & $17.8 \pm 1.1 \#$ \\
\hline Primary somatosensory cortex, Layer III & $15.1 \pm 1.0$ & $11.7 \pm 0.4 *$ & $14.6 \pm 0.8$ & $11.2 \pm 0.4^{\#}$ \\
\hline Primary somatosensory cortex, Layer V & $13.4 \pm 0.4$ & $12.3 \pm 0.5 *$ & $15.0 \pm 0.7$ & $11.7 \pm 0.3^{\#}$ \\
\hline Ectorhinal cortex, Layer I & $16.7 \pm 0.4$ & $14.7 \pm 0.9 *$ & $17.2 \pm 0.8$ & $14.5 \pm 0.3^{\#}$ \\
\hline Ectorhinal cortex, Layer III & $15.4 \pm 0.9$ & $13.1 \pm 0.6 *$ & $17.1 \pm 0.3$ & $13.5 \pm 0.5^{\#}$ \\
\hline Ectorhinal cortex, Layer V & $14.5 \pm 0.2$ & $11.7 \pm 0.4 *$ & $14.3 \pm 0.3$ & $12.2 \pm 0.4^{\#}$ \\
\hline Lateral entorhinal, Layer I & $17.2 \pm 1.4$ & $14.4 \pm 0.6 *$ & $18.8 \pm 0.9$ & $14.8 \pm 0.2^{\#}$ \\
\hline Lateral entorhinal, Layer III & $15.6 \pm 1.2$ & $11.8 \pm 0.4 *$ & $16.8 \pm 0.6$ & $11.8 \pm 0.3^{\#}$ \\
\hline Lateral entorhinal, Layer V & $13.5 \pm 0.8$ & $12.0 \pm 0.2 *$ & $14.5 \pm 0.7$ & $11.2 \pm 0.3^{\#}$ \\
\hline \multicolumn{5}{|l|}{ Hippocampal formation } \\
\hline CA1 & $21.3 \pm 1.1$ & $18.3 \pm 0.4 *$ & $21.3 \pm 1.2$ & $17.3 \pm 0.8^{\#}$ \\
\hline CA2 & $18.8 \pm 0.9$ & $15.1 \pm 0.4 *$ & $17.6 \pm 0.7$ & $14.4 \pm 0.5^{\#}$ \\
\hline CA3 & $20.9 \pm 0.8$ & $16.5 \pm 0.4 *$ & $20.3 \pm 0.8$ & $16.5 \pm 0.6 \#$ \\
\hline Dentate gyrus & $23.4 \pm 0.5$ & $20.4 \pm 0.3 *$ & $23.0 \pm 0.8$ & $19.4 \pm 1.2^{\#}$ \\
\hline
\end{tabular}

Values are represented as means \pm S.E.M. from 5 individual mice in each group. Statistical analysis was performed using one-way ANOVA followed by Student-Newman-Keuls test. (* $\mathrm{p}<0.05$ was compared with the saline-treated wild type mice; ${ }^{*} \mathrm{p}<0.05$ was compared with the saline-treated $\mu$-opioid receptor knockout mice) 
with multiple neurotransmitter systems including muscarinic, GABAergic, dopaminergic and glutamatergic neurons.

Tolerance develops to DFP-induced tremors in wild type mice remains after 28 days of administration, despite the fact that acetylcholinesterase activity at approximately $32 \%$ of control levels throughout this period. These data support a conclusion that recovery of acetylcholinesterase activity is not required for development of tolerance to DFP-induced behaviors (Bushnell et al., 1993; Dettbarn et al., 1999; Prendergast et al., 1998). Previous studies have dem- onstrated that continuous administration of DFP can lead to muscarinic receptor down-regulation (Churchill et al., 1984; Ehlert et al., 1980). Similarly, we found binding of $\left[{ }^{3} \mathrm{H}\right]-\mathrm{QNB},\left[{ }^{3} \mathrm{H}\right]-\mathrm{PZ}$, and $\left[{ }^{3} \mathrm{H}\right]$ AF-DX 384 was decreased in subacute DFP-treated $\mu$-opioid receptor knockout and wild type mice as compared with that of saline-treated controls. However, down-regulation of muscarinic receptors after repeated exposure to DFP is not the same in all brain regions, and correlates with topographic distribution of muscarinic receptors (Ehlert et al., 1980). M1 subtype muscarinic receptors are abundantly distributed in all major forebrain areas,

Table 4. Effects of repeated administration (7 days) of DFP on binding of $\left[{ }^{3} \mathrm{H}\right]-\mathrm{AF}-\mathrm{DX} 384$ to $\mathrm{M} 2$ muscarinic cholinergic receptors in coronal brain sections of the wild type and $\mu$-opioid receptor knockout mice.

\begin{tabular}{|c|c|c|c|c|}
\hline \multirow{3}{*}{ Brain region } & \multicolumn{4}{|c|}{$\left[{ }^{3} \mathrm{H}\right]-\mathrm{AF}-\mathrm{DX} 384$ binding (nCi/mg tissue) } \\
\hline & \multicolumn{2}{|c|}{ Wild type } & \multicolumn{2}{|c|}{$\mu$-Knockout } \\
\hline & Saline & $\begin{array}{c}\text { DFP } \\
(1 \mathrm{mg} / \mathrm{kg}, 7 \text { days })\end{array}$ & Saline & $\begin{array}{c}\text { DFP } \\
(1 \mathrm{mg} / \mathrm{kg}, 7 \text { days })\end{array}$ \\
\hline \multicolumn{5}{|l|}{ Striatal complex } \\
\hline Caudate-putamen & $25.5 \pm 1.2$ & $18.3 \pm 1.0 *$ & $21.4 \pm 0.9 *$ & $14.9 \pm 0.3^{\# \$}$ \\
\hline Nucleus accumbens & $22.0 \pm 0.8$ & $17.3 \pm 1.0 *$ & $18.1 \pm 0.9 *$ & $16.1 \pm 0.4^{\# \$}$ \\
\hline \multicolumn{5}{|l|}{ Cortex } \\
\hline Retrosplenial agranular, Layer I & $14.9 \pm 0.6$ & $12.5 \pm 1.4$ & $12.9 \pm 0.7$ & $11.8 \pm 1.6$ \\
\hline Retrosplenial agranular, Layer III & $15.6 \pm 0.6$ & $14.0 \pm 0.7$ & $14.9 \pm 0.4$ & $13.2 \pm 1.0$ \\
\hline Retrosplenial agranular, Layer $\mathrm{V}$ & $15.9 \pm 0.6$ & $14.7 \pm 0.4$ & $16.3 \pm 0.7$ & $13.4 \pm 0.5$ \\
\hline Primary somatosensory cortex, Layer I & $15.7 \pm 0.7$ & $13.5 \pm 1.0$ & $14.1 \pm 0.3$ & $14.0 \pm 0.9$ \\
\hline Primary somatosensory cortex, Layer III & $13.3 \pm 0.3$ & $11.6 \pm 0.5$ & $13.2 \pm 0.3$ & $11.0 \pm 0.3$ \\
\hline Primary somatosensory cortex, Layer V & $14.4 \pm 0.4$ & $12.9 \pm 0.1$ & $14.5 \pm 0.5$ & $13.2 \pm 0.5$ \\
\hline Ectorhinal cortex, Layer I & $10.8 \pm 0.5$ & $10.7 \pm 0.3$ & $10.6 \pm 0.3$ & $10.5 \pm 0.5$ \\
\hline Ectorhinal cortex, Layer III & $13.1 \pm 0.5$ & $11.4 \pm 0.5$ & $12.6 \pm 0.4$ & $12.2 \pm 0.2$ \\
\hline Ectorhinal cortex, Layer V & $13.8 \pm 0.5$ & $12.6 \pm 0.6$ & $14.3 \pm 0.5$ & $12.4 \pm 0.5$ \\
\hline Lateral entorhinal, Layer I & $8.5 \pm 0.4$ & $8.3 \pm 0.1$ & $8.9 \pm 0.4$ & $8.7 \pm 0.2$ \\
\hline Lateral entorhinal, Layer III & $9.6 \pm 0.4$ & $9.6 \pm 0.4$ & $10.5 \pm 0.4$ & $9.7 \pm 0.6$ \\
\hline Lateral entorhinal, Layer V & $12.3 \pm 0.5$ & $10.9 \pm 0.5$ & $12.8 \pm 0.7$ & $11.0 \pm 0.6$ \\
\hline \multicolumn{5}{|l|}{ Hippocampal formation } \\
\hline CA1 & $7.9 \pm 0.2$ & $7.2 \pm 0.3$ & $8.0 \pm 0.5$ & $7.5 \pm 0.1$ \\
\hline CA2 & $8.3 \pm 0.4$ & $7.8 \pm 0.3$ & $8.7 \pm 0.3$ & $8.1 \pm 0.4$ \\
\hline CA3 & $8.6 \pm 0.3$ & $8.0 \pm 0.3$ & $7.9 \pm 0.3$ & $8.1 \pm 0.2$ \\
\hline Dentate gyrus & $10.6 \pm 0.3$ & $9.9 \pm 0.6$ & $10.7 \pm 0.5$ & $9.2 \pm 0.3$ \\
\hline
\end{tabular}

Values are represented as means \pm S.E.M. from 5 individual mice in each group. Statistical analysis was performed using one-way ANOVA followed by Student-Newman-Keuls test. (* $\mathrm{p}<0.05$ was compared with the saline-treated wild type mice; ${ }^{*} \mathrm{p}<0.05$ was compared with the saline-treated $\mu$-opioid receptor knockout mice; ${ }^{\$} \mathrm{p}<0.05$ was compared with the DFP-treated wild type mice) 
DFP in $\mu$-opioid receptor knockout mice.

with particularly high density in the cortex, hippocampus and striatum (Levey, 1993); while M2 subtype muscarinic receptors are predominately distributed in the striatum and brainstem (Levey, 1993). This may explain why DFP-induced down-regulation of M1 subtype muscarinic receptor binding began earlier than that of M2 subtype muscarinic receptor binding in the cortex and hippocampus. Thus, we found down-regulation of M1 subtype muscarinic receptor binding in the cortex, striatum and hippocampus of DFP treated $\mu$ opioid receptor knockout and wild type mice after subacute administration of DFP for 7 days. In contrast, down-regulation of M2 subtype muscarinic receptor binding was noted only in the striatum of DFP treated $\mu$-opioid receptor knockout and wild type mice after subacute administration of DFP for 7 days.

Tolerance developed to DFP-induced tremors but not to chewing movements despite down-regulation of total, M1 and M2 muscarinic receptors in the cortex, striatum and hippocampus of both DFP-treated $\mu$-opioid receptor knockout and wild type mice. These results suggest that down-regulation of muscarinic receptors is not required for development of tolerance to DFP-induced behaviors. This confirms results of a

Table 5. Effects of repeated administration (28 days) of DFP on binding of $\left[{ }^{3} \mathrm{H}\right]$-quinuclidinyl benzilate to muscarinic cholinergic receptors in coronal brain sections of the wild type and $\mu$-opioid receptor knockout mice.

\begin{tabular}{|c|c|c|c|c|}
\hline \multirow{3}{*}{ Brain region } & \multicolumn{4}{|c|}{$\left[{ }^{3} \mathrm{H}\right]-\mathrm{QNB}$ binding (nCi/mg tissue) } \\
\hline & \multicolumn{2}{|c|}{ Wild type } & \multicolumn{2}{|c|}{$\mu$-Knockout } \\
\hline & Saline & $\begin{array}{c}\text { DFP } \\
(1 \mathrm{mg} / \mathrm{kg}, 28 \text { days })\end{array}$ & Saline & $\begin{array}{c}\text { DFP } \\
(1 \mathrm{mg} / \mathrm{kg}, 28 \text { days })\end{array}$ \\
\hline \multicolumn{5}{|l|}{ Striatal complex } \\
\hline Caudate-putamen & $25.4 \pm 1.5$ & $15.2 \pm 0.2 *$ & $24.2 \pm 0.5$ & $14.4 \pm 0.3^{\#}$ \\
\hline Nucleus accumbens & $24.8 \pm 1.1$ & $15.3 \pm 0.4 *$ & $22.0 \pm 0.8$ & $14.6 \pm 0.7^{\#}$ \\
\hline \multicolumn{5}{|l|}{ Cortex } \\
\hline Retrosplenial agranular, Layer I & $14.1 \pm 0.6$ & $9.1 \pm 0.4 *$ & $12.2 \pm 1.0$ & $9.7 \pm 0.3^{\#}$ \\
\hline Retrosplenial agranular, Layer III & $11.5 \pm 0.5$ & $6.7 \pm 0.3 *$ & $11.3 \pm 0.8$ & $7.3 \pm 0.6^{\#}$ \\
\hline Retrosplenial agranular, Layer V & $10.9 \pm 0.5$ & $6.6 \pm 0.4 *$ & $10.5 \pm 0.8$ & $6.7 \pm 0.4$ \# \\
\hline Primary somatosensory cortex, Layer I & $17.6 \pm 0.5$ & $13.5 \pm 0.3 *$ & $17.2 \pm 0.9$ & $13.8 \pm 0.9^{\#}$ \\
\hline Primary somatosensory cortex, Layer III & $11.2 \pm 0.3$ & $8.3 \pm 0.3 *$ & $11.7 \pm 1.1$ & $8.8 \pm 0.5^{\#}$ \\
\hline Primary somatosensory cortex, Layer V & $11.9 \pm 0.6$ & $8.9 \pm 1.2 *$ & $11.4 \pm 0.8$ & $9.3 \pm 0.6 \#$ \\
\hline Ectorhinal cortex, Layer I & $12.4 \pm 0.7$ & $8.6 \pm 0.4 *$ & $12.0 \pm 1.0$ & $8.6 \pm 0.3^{\#}$ \\
\hline Ectorhinal cortex, Layer III & $10.8 \pm 0.7$ & $7.2 \pm 0.4 *$ & $9.8 \pm 0.8$ & $7.1 \pm 0.6^{\#}$ \\
\hline Ectorhinal cortex, Layer V & $11.6 \pm 0.3$ & $7.4 \pm 0.2 *$ & $11.3 \pm 0.9$ & $7.6 \pm 0.3^{\#}$ \\
\hline Lateral entorhinal, Layer I & $12.4 \pm 0.6$ & $9.2 \pm 0.3 *$ & $12.1 \pm 0.7$ & $9.2 \pm 0.7$ \# \\
\hline Lateral entorhinal, Layer III & $12.4 \pm 0.7$ & $9.0 \pm 0.3 *$ & $11.3 \pm 0.6$ & $8.9 \pm 0.8^{\#}$ \\
\hline Lateral entorhinal, Layer V & $11.0 \pm 0.5$ & $7.3 \pm 0.2 *$ & $10.3 \pm 0.8$ & $6.9 \pm 0.4$ \# \\
\hline \multicolumn{5}{|l|}{ Hippocampal formation } \\
\hline CA1 & $13.7 \pm 0.9$ & $10.7 \pm 0.8 *$ & $12.7 \pm 0.8$ & $8.6 \pm 1.0^{\#}$ \\
\hline $\mathrm{CA} 2$ & $12.3 \pm 1.0$ & $9.6 \pm 0.7 *$ & $11.8 \pm 0.3$ & $8.9 \pm 0.2^{\#}$ \\
\hline CA3 & $13.8 \pm 0.6$ & $10.6 \pm 0.4 *$ & $13.8 \pm 1.1$ & $10.8 \pm 1.0^{\#}$ \\
\hline Dentate gyrus & $14.2 \pm 0.3$ & $11.5 \pm 0.6 *$ & $13.6 \pm 0.8$ & $11.0 \pm 1.1 \#$ \\
\hline
\end{tabular}

Values are represented as means \pm S.E.M. from 5 individual mice in each group. Statistical analysis was performed using one-way ANOVA followed by Student-Newman-Keuls test. ( ${ }^{*} \mathrm{p}<0.05$ was compared with the saline-treated wild type mice; ${ }^{\#} \mathrm{p}<0.05$ was compared with the saline-treated $\mu$-opioid receptor knockout mice) 


\section{L.-T. TIEN et al.}

previous study in which the changes in DFP responses did not parallel to changes in $\left[{ }^{3} \mathrm{H}\right]-\mathrm{QNB}$ binding (Smolen et al., 1986). In addition, in our study DFPtreated $\mu$-opioid receptor knockout mice showed significantly greater tremors than did wild type groups, despite equivalent reduction in muscarinic receptor density between the two groups. These results indicate that difference in the degree of development of tolerance to DFP-induced tremors between $\mu$-opioid receptor knockout and wild type mice is not related to downregulation of muscarinic receptors.

In addition to acetylcholinesterase activity and down-regulation of postsynaptic muscarinic receptors, many other possible factors such as presynaptic cholinergic subsensitivity (Lim et al., 1987; Thomsen and Wilson, 1988) or dopamine turnover rate (Potter et al., 1984) are involved in the development of tolerance to various DFP-induced behaviors. In this study, we found that $\mu$-Opioid receptors are also involved in development of tolerance to DFP-induced tremors. $\mu$ Opioid receptors regulate the tolerance development to DFP involves alterations in the functional presynaptic cholinergic neurons rather than postsynaptic muscarinic receptors. In order to understand the relationship

Table 6. Effects of repeated administration (28 days) of DFP on binding of $\left[{ }^{3} \mathrm{H}\right]$-pirenzepine to M1 muscarinic cholinergic receptors in coronal brain sections of the wild type and $\mu$-opioid receptor knockout mice.

\begin{tabular}{|c|c|c|c|c|}
\hline \multirow{3}{*}{ Brain region } & \multicolumn{4}{|c|}{$\left[{ }^{3} \mathrm{H}\right]-\mathrm{PZ}$ binding (nCi/mg tissue) } \\
\hline & \multicolumn{2}{|c|}{ Wild type } & \multicolumn{2}{|c|}{$\mu$-Knockout } \\
\hline & Saline & $\begin{array}{c}\text { DFP } \\
(1 \mathrm{mg} / \mathrm{kg}, 28 \text { days })\end{array}$ & Saline & $\begin{array}{c}\text { DFP } \\
(1 \mathrm{mg} / \mathrm{kg}, 28 \text { days })\end{array}$ \\
\hline \multicolumn{5}{|l|}{ Striatal complex } \\
\hline Caudate-putamen & $23.8 \pm 0.8$ & $17.7 \pm 0.4 *$ & $22.4 \pm 0.5$ & $17.6 \pm 1.0^{\#}$ \\
\hline Nucleus accumbens & $24.5 \pm 1.1$ & $18.4 \pm 0.5 *$ & $23.6 \pm 0.6$ & $18.0 \pm 0.7^{\#}$ \\
\hline \multicolumn{5}{|l|}{ Cortex } \\
\hline Retrosplenial agranular, Layer I & $19.8 \pm 0.9$ & $11.4 \pm 0.5 *$ & $19.0 \pm 0.7$ & $11.2 \pm 0.5^{\#}$ \\
\hline Retrosplenial agranular, Layer III & $11.9 \pm 0.5$ & $10.2 \pm 0.6 *$ & $11.6 \pm 0.6$ & $9.6 \pm 0.3^{\#}$ \\
\hline Retrosplenial agranular, Layer V & $12.3 \pm 0.9$ & $9.0 \pm 0.9 *$ & $12.0 \pm 0.5$ & $8.8 \pm 0.3^{\#}$ \\
\hline Primary somatosensory cortex, Layer I & $19.7 \pm 1.0$ & $14.3 \pm 0.5 *$ & $19.4 \pm 0.8$ & $14.2 \pm 0.3^{\#}$ \\
\hline Primary somatosensory cortex, Layer III & $13.5 \pm 0.5$ & $10.8 \pm 0.4 *$ & $13.2 \pm 0.3$ & $10.4 \pm 0.5^{\#}$ \\
\hline Primary somatosensory cortex, Layer V & $13.6 \pm 0.5$ & $10.0 \pm 0.2 *$ & $13.6 \pm 0.4$ & $9.7 \pm 0.5^{\#}$ \\
\hline Ectorhinal cortex, Layer I & $18.5 \pm 1.1$ & $13.6 \pm 0.4 *$ & $18.0 \pm 0.6$ & $13.5 \pm 0.5$ \# \\
\hline Ectorhinal cortex, Layer III & $15.0 \pm 1.0$ & $11.2 \pm 0.4 *$ & $14.6 \pm 0.4$ & $11.0 \pm 0.5^{\#}$ \\
\hline Ectorhinal cortex, Layer V & $14.2 \pm 1.0$ & $10.9 \pm 0.5 *$ & $14.2 \pm 0.3$ & $10.9 \pm 0.4^{\#}$ \\
\hline Lateral entorhinal, Layer I & $18.3 \pm 1.3$ & $13.8 \pm 0.7 *$ & $18.0 \pm 0.4$ & $13.4 \pm 0.6^{\#}$ \\
\hline Lateral entorhinal, Layer III & $14.1 \pm 1.1$ & $10.9 \pm 0.3 *$ & $13.9 \pm 0.2$ & $10.9 \pm 0.5 \#$ \\
\hline Lateral entorhinal, Layer V & $13.7 \pm 0.9$ & $9.5 \pm 0.1 *$ & $13.2 \pm 0.5$ & $9.0 \pm 0.2^{\#}$ \\
\hline \multicolumn{5}{|l|}{ Hippocampal formation } \\
\hline CA1 & $22.5 \pm 1.6$ & $17.1 \pm 0.4 *$ & $22.5 \pm 0.6$ & $16.5 \pm 0.8^{\#}$ \\
\hline $\mathrm{CA} 2$ & $19.8 \pm 1.2$ & $15.2 \pm 0.8 *$ & $18.9 \pm 1.0$ & $15.2 \pm 0.7^{\#}$ \\
\hline CA3 & $19.5 \pm 1.0$ & $15.2 \pm 0.5 *$ & $19.4 \pm 0.6$ & $15.0 \pm 0.4^{\#}$ \\
\hline Dentate gyrus & $21.6 \pm 1.9$ & $16.8 \pm 0.8 *$ & $20.8 \pm 0.9$ & $16.1 \pm 0.5^{\#}$ \\
\hline
\end{tabular}

Values are represented as means \pm S.E.M. from 5 individual mice in each group. Statistical analysis was performed using one-way ANOVA followed by Student-Newman-Keuls test. $\quad\left({ }^{*} \mathrm{p}<0.05\right.$ was compared with the saline-treated wild type mice; ${ }^{*} \mathrm{p}<0.05$ was compared with the saline-treated $\mu$-opioid receptor knockout mice) 
DFP in $\mu$-opioid receptor knockout mice.

between $\mu$-opioid receptors and presynaptic cholinergic function in development of tolerance to DFP, further studies such as acetylcholine release or choline uptake will be necessary.

\section{ACKNOWLEDGMENT}

The authors thank Dr. Susan E. Wellman for her generous help in Cyclone Storage Phosphor System and Dr. Robin W. Rockhold for comments on discussion of this manuscript. The project was supported by research funds Grant R06/CCR419466 from the Cen- ters for Disease Control and Prevention (to IKH) and the Center of Psychiatric Neuroscience at the UMMC (to TM) which is supported by NIH Grant RR-P20 RR17701.

\section{REFERENCES}

Alexander, G.E. and Crutcher, M.D. (1990): Functional architecture of basal ganglia circuits: Neural substrates of parallel processing. Trends. Neurosci., 13, 266-271.

Buccafusco, J.J., Zhang, L.C., Shuster, L.C., Jonnala,

Table 7. Effects of repeated administration (28 days) of DFP on binding of $\left[{ }^{3} \mathrm{H}\right]-\mathrm{AF}-\mathrm{DX} 384$ to M 2 muscarinic cholinergic receptors in coronal brain sections of the wild type and $\mu$-opioid receptor knockout mice.

\begin{tabular}{|c|c|c|c|c|}
\hline \multirow{3}{*}{ Brain region } & \multicolumn{4}{|c|}{$\left[{ }^{3} \mathrm{H}\right]-\mathrm{AF}-\mathrm{DX} 384$ binding (nCi/mg tissue) } \\
\hline & \multicolumn{2}{|c|}{ Wild type } & \multicolumn{2}{|c|}{$\mu$-Knockout } \\
\hline & Saline & $\begin{array}{c}\text { DFP } \\
(1 \mathrm{mg} / \mathrm{kg}, 28 \text { days })\end{array}$ & Saline & $\begin{array}{c}\text { DFP } \\
(1 \mathrm{mg} / \mathrm{kg}, 28 \text { days })\end{array}$ \\
\hline \multicolumn{5}{|l|}{ Striatal complex } \\
\hline Caudate-putamen & $25.8 \pm 0.5$ & $13.3 \pm 1.0 *$ & $20.3 \pm 0.4 *$ & $10.7 \pm 0.5$ \#\$ \\
\hline Nucleus accumbens & $22.2 \pm 1.2$ & $11.4 \pm 0.7 *$ & $18.4 \pm 0.7 *$ & $9.6 \pm 0.4$ \# \\
\hline \multicolumn{5}{|l|}{ Cortex } \\
\hline Retrosplenial agranular, Layer I & $14.1 \pm 0.9$ & $10.3 \pm 0.3 *$ & $14.3 \pm 0.5$ & $9.9 \pm 0.8 \#$ \\
\hline Retrosplenial agranular, Layer III & $15.1 \pm 0.4$ & $9.5 \pm 0.5 *$ & $13.5 \pm 0.8$ & $8.5 \pm 0.5$ \# \\
\hline Retrosplenial agranular, Layer V & $15.8 \pm 0.5$ & $7.5 \pm 0.6 *$ & $15.2 \pm 0.7$ & $7.4 \pm 1.1^{\#}$ \\
\hline Primary somatosensory cortex, Layer I & $14.6 \pm 1.8$ & $12.0 \pm 2.1 *$ & $13.3 \pm 0.4$ & $11.1 \pm 1.0 \#$ \\
\hline Primary somatosensory cortex, Layer III & $12.1 \pm 0.4$ & $8.4 \pm 0.4 *$ & $11.9 \pm 0.5$ & $8.2 \pm 0.5$ \# \\
\hline Primary somatosensory cortex, Layer V & $11.4 \pm 0.3$ & $9.5 \pm 1.2 *$ & $11.2 \pm 0.9$ & $8.5 \pm 1.0$ \# \\
\hline Ectorhinal cortex, Layer I & $13.6 \pm 1.1$ & $9.1 \pm 0.7 *$ & $12.8 \pm 0.7$ & $8.4 \pm 0.4$ \# \\
\hline Ectorhinal cortex, Layer III & $10.5 \pm 0.7$ & $8.3 \pm 0.3 *$ & $9.9 \pm 0.7$ & $7.9 \pm 0.4^{\#}$ \\
\hline Ectorhinal cortex, Layer V & $12.7 \pm 0.7$ & $8.2 \pm 0.3 *$ & $12.3 \pm 0.5$ & $7.9 \pm 0.5^{\#}$ \\
\hline Lateral entorhinal, Layer I & $11.9 \pm 0.1$ & $7.9 \pm 0.1 *$ & $11.4 \pm 1.1$ & $7.8 \pm 0.5^{\#}$ \\
\hline Lateral entorhinal, Layer III & $10.8 \pm 0.1$ & $7.5 \pm 0.4 *$ & $9.9 \pm 0.5$ & $7.4 \pm 0.3^{\#}$ \\
\hline Lateral entorhinal, Layer V & $12.2 \pm 0.3$ & $9.4 \pm 0.3 *$ & $11.4 \pm 0.9$ & $8.9 \pm 0.7$ \# \\
\hline \multicolumn{5}{|l|}{ Hippocampal formation } \\
\hline CA1 & $8.0 \pm 0.4$ & $5.9 \pm 0.3 *$ & $7.9 \pm 0.5$ & $5.3 \pm 0.3 \#$ \\
\hline CA2 & $7.2 \pm 0.3$ & $5.5 \pm 0.2 *$ & $6.9 \pm 0.6$ & $5.3 \pm 0.2^{\#}$ \\
\hline CA3 & $8.2 \pm 0.3$ & $5.7 \pm 0.3 *$ & $7.5 \pm 0.4$ & $5.6 \pm 0.5^{\#}$ \\
\hline Dentate gyrus & $9.4 \pm 0.2$ & $5.8 \pm 0.2 *$ & $8.7 \pm 0.4$ & $5.4 \pm 0.1{ }^{\#}$ \\
\hline
\end{tabular}

Values are represented as means \pm S.E.M. from 5 individual mice in each group. Statistical analysis was performed using one-way ANOVA followed by Student-Newman-Keuls test. (* $\mathrm{p}<0.05$ was compared with the saline-treated wild type mice; ${ }^{\#} \mathrm{p}<0.05$ was compared with the saline-treated $\mu$-opioid receptor knockout mice; $\$ p<0.05$ was compared with the DFP-treated wild type mice) 
R.R. and Gattu, M. (2000): Prevention of precipitated withdrawal symptoms by activating central cholinergic systems during a dependence-producing schedule of morphine in rats. Brain Res., 852, 76-83.

Bushnell, P.J., Padilla, S.S., Ward, T., Pope, C.N. and Olszyk, V.B. (1991): Behavioral and neurochemical changes in rats dosed repeatedly with diisopropylfluorophosphate. J. Pharmacol. Exp. Ther., 256, 741-750.

Bushnell, P.J., Pope, C.N. and Padilla, S. (1993): Behavioral and neurochemical effects of acute chlorpyrifos in rats: Tolerance to prolonged inhibition of cholinesterase. J. Pharmacol. Exp. Ther., 266, 1007-1017.

Bymaster, F.P., Carter, P.A., Zhang, L., Falcone, J.F., Stengel, P.W., Cohen, M.L., Shannon, H.E., Gomeza, J., Wess, J. and Felder, C.C. (2001): Investigations into the physiological role of muscarinic M2 and M4 muscarinic and M4 receptor subtypes using receptor knockout mice. Life Sci., 68, 2473-2479.

Churchill, L., Pazdernik, T.L., Samson, F. and Nelson, S.R. (1984): Topographical distribution of down-regulated muscarinic receptors in rat brains after repeated exposure to diisopropyl phosphorofluoridate. Neuroscience, 11, 463472.

Cousins, M.S., Finn, M., Trevitt, J., Carriero, D.L., Conlan, A. and Salamone, J.D. (1999): The role of ventrolateral striatal acetylcholine in the production of tacrine-induced jaw movements. Pharmacol. Biochem. Behav., 62, 439-447.

Dettbarn, W.D., Yang, Z.P. and Milatovic, D. (1999): Different role of carboxylesterases in toxicity and tolerance to paraoxon and DFP. Chem. Biol. Interact., 119-120, 445-454.

Di Chiara, G., Morelli, M. and Consolo, S. (1994): Modulatory functions of neurotransmitters in the striatum: ACh/dopamine/NMDA interactions. Trends. Neurosci., 17, 228-233.

Dulaney, M.D. Jr., Rockhold, R.W., Porter, A.C., Hoskins, B. and Ho, I.K. (1989): Changes in drinking activity, urine volume and urinary electrolyte excretion after intracerebroventricular administration of diisopropylfluorophosphate. J. Pharmacol. Exp. Ther., 250, 202-209.

Ehlert, F.J., Kokka, N. and Fairhurst, A.S. (1980): Altered $\left[{ }^{3} \mathrm{H}\right]$ quinuclidinyl benzilate binding in the striatum of rats following chronic cholinesterase inhibition with diisopropylfluorophos- phate. Mol. Pharmacol., 17, 24-30.

Feldman, R.S., Mayer, J.S. and Quenzer, L.F. (1997): Principles of neuropsychopharmacology. Sunderland Mass., Sinauer Associates, pp. 237.

Fernando, J.C., Hoskins, B. and Ho, I.K. (1984): Effect on striatal dopamine metabolism and differential motor behavioral tolerance following chronic cholinesterase inhibition with diisopropylfluorophosphate. Pharmacol. Biochem. Behav., 20, 951-957.

Feuerstein, T.J., Gleichauf, O., Peckys, D., Landwehrmeyer, G.B., Scheremet, R. and Jackisch, R. (1996): Opioid receptor-mediated control of acetylcholine release in human neocortex tissue. Naunyn Schmiedebergs Arch. Pharmacol., 354, 586-592.

Franklin, K.B.J. and Paxinos, G. (1997): The Mouse Brain in stereotaxic Coordinates, Academic Press.

Gattu, M., Wei, J., Pauly, J.R., Urbanawiz, S. and Buccafusco, J.J. (1997): Increased expression of M2 muscarinic receptor mRNA and binding sites in the rostral ventrolateral medulla of spontaneously hypertensive rats. Brain Res., 756, 125-132.

Gazyakan, E., Hennegriff, M., Haaf, A., Landwehrmeyer, G.B., Feuerstein, T.J. and Jackisch, R. (2000): Characterization of opioid receptor types modulating acetylcholine release in septal regions of the rat brain. Naunyn Schmiedebergs Arch. Pharmacol., 362, 32-40.

Glow, P.H., Richardson, A. and Rose, S. (1966): Effects of acute and chronic inhibition of cholinesterase upon body weight, food intake, and water intake in the rat. J. Comp. Physiol. Psychol., 61, 295-299.

Gomeza, J., Zhang, L., Kostenis, E., Felder, C.C., Bymaster, F.P., Brodkin, J., Shannon, H., Xia, B., Duttaroy, A., Deng, C.X. and Wess, J. (2001): Generation and pharmacological analysis of M2 and M4 muscarinic receptor knockout mice. Life Sci., 68, 2457-2466.

Gordon, C.J. (1993): Acute and delayed effects of diisopropyl fluorophosphate on body temperature, heart rate, and motor activity in the awake, unrestrained rat. J. Toxicol. Environ. Health, 39, 247-260.

Graybiel, A.M., Aosaki, T., Flaherty, A.W. and Kimura, M. (1994): The basal ganglia and adaptive motor control. Science, 265, 1826-1831.

Green, J.P., Glick, S.D., Crane, A.M. and Szilagyi, P.I. 
DFP in $\mu$-opioid receptor knockout mice.

(1976): Acute effects of morphine on regional brain levels of acetylcholine in mice and rats. Eur. J. Pharmacol., 39, 91-99.

Groenewegen, H.J., Wright, C.I. and Beijer, A.V. (1996): The nucleus accumbens: Gateway for limbic structures to reach the motor system? Prog. Brain Res., 107, 485-511.

Harsing, L.G. Jr. and Zigmond, M.J. (1998): Postsynaptic integration of cholinergic and dopaminergic signals on medium-sized GABAergic projection neurons in the neostriatum. Brain Res. Bull., 45, 607-613.

Hozumi, S., Nakagawasai, O., Tan-No, K., Niijima, F., Yamadera, F., Murata, A., Arai, Y., Yasuhara, H. and Tadano, T. (2003): Characteristics of changes in cholinergic function and impairment of learning and memory-related behavior induced by olfactory bulbectomy. Behav. Brain Res., 138, 9-15.

Imperato, A., Obinu, M.C., Casu, M.A., Mascia, M.S., Carta, G. and Gessa, G.L. (1996): Chronic morphine increases hippocampal acetylcholine release: Possible relevance in drug dependence. Eur. J. Pharmacol., 302, 21-26.

Kelley, A.E. (1999): Functional specificity of ventral striatal compartments in appetitive behaviors. Ann. N Y Acad. Sci., 877, 71-90.

Kelley, A.E., Bakshi, V.P., Delfs, J.M. and Lang, C.G. (1989): Cholinergic stimulation of the ventrolateral striatum elicits mouth movements in rats: Pharmacological and regional specificity. Psychopharmacology, 99, 542-549.

Koene, P., Prinssen, E.P. and Cools, A.R. (1993): Involvement of the nucleus accumbens in oral behaviour in the freely moving rat. Eur. J. Pharmacol., 233, 151-156.

Koshikawa, N., Tomiyama, K., Omiya, K., de Beltran, K.K. and Kobayashi, M. (1990): Dopamine D-1 but not D-2 receptor stimulation of the dorsal striatum potentiates apomorphine-induced jaw movements in rats. Eur. J. Pharmacol., 178, 189-194.

Lapchak, P.A., Araujo, D.M. and Collier, B. (1989): Regulation of endogenous acetylcholine release from mammalian brain slices by opiate receptors: Hippocampus, striatum and cerebral cortex of guinea-pig and rat. Neuroscience, 31, 313325.

Levey, A.I. (1993): Immunological localization of m1m5 muscarinic acetylcholine receptors in peripheral tissues and brain. Life Sci., 52, 441-
448.

Lim, D.K., Fernando, J.C., Hoskins, B. and Ho, I.K. (1987); Quantitative assessment of tolerance development to diisopropylfluorophosphate. Pharmacol. Biochem. Behav., 26, 281-286.

Lim, D.K., Hoskins, B. and Ho, I.K. (1983): Assessment of diisopropylfluorophosphate (DFP) toxicity and tolerance in rats. Res. Commun. Chem. Pathol. Pharmacol., 39, 399-418.

Lim, D.K., Ito, Y., Hoskins, B. and Ho, I.K. (1988): Effects of acute and subacute administration of bicuculline on dopamine and muscarinic receptors in rat brain. Brain Res. Bull., 21, 21-24.

Loh, H.H., Liu, H.C., Cavalli, A., Yang, W., Chen, Y.F. and Wei, L.N. (1998): Mu-opioid receptor knockout in mice: Effects on ligand-induced analgesia and morphine lethality. Brain Res. Mol. Brain Res., 54, 321-326.

Ma, T., Cai, Z., Wellman, S.E. and Ho, I.K. (2001): A quantitative histochemistry technique for measuring regional distribution of acetylcholinesterase in the brain using digital scanning densitometry. Anal. Biochem., 296, 18-28.

Mattio, T.G., Richardson, J.S. and Giacobini, E. (1984): Effects of DFP on iridic metabolism and release of acetylcholine and on pupillary function in the rat. Neuropharmacology, 23, 12071214.

Overstreet, D.H. (1973): The effects of pilocarpine on the drinking behavior of rats following acute and chronic treatment with diisopropylfluorophosphate and during withdrawal. Behav. Biol., 9, 257-263.

Padmanabha Pillai, N., Ramaswamy, S., Gopalakrishnan, V. and Ghosh, M.N. (1982): Effect of cholinergic drugs on acute and chronic morphine dependence. Arch. Int. Pharmacodyn. Ther., 257, 146-154.

Pisani, A., Bonsi, P., Centonze, D., Calabresi, P. and Bernardi, G. (2000): Activation of D2-like dopamine receptors reduces synaptic inputs to striatal cholinergic interneurons. J. Neurosci., 20, RC69.

Potter, P.E., Hadjiconstantinou, M., Rubenstein, J.S. and Neff, N.H. (1984): Chronic treatment with diisopropylfluorophosphate increases dopamine turnover in the striatum of the rat. Eur. J. Pharmacol., 106, 607-611.

Prendergast, M.A., Terry, A.V. Jr. and Buccafusco, J.J. (1997): Chronic, low-level exposure to diisopropylfluorophosphate causes protracted impairment 
of spatial navigation learning. Psychopharmacology, 129, 183-191.

Prendergast, M.A., Terry, A.V. Jr. and Buccafusco, J.J. (1998): Effects of chronic, low-level organophosphate exposure on delayed recall, discrimination, and spatial learning in monkeys and rats. Neurotoxicol. Teratol., 20, 115-122.

Robbins, T.W. and Everitt, B.J. (1996): Neurobehavioural mechanisms of reward and motivation. Curr. Opin. Neurobiol., 6, 228-236.

Russell, R.W. and Overstreet, D.H. (1987): Mechanisms underlying sensitivity to organophosphorus anticholinesterase compounds. Prog. Neurobiol., 28, 97-129.

Russell, R.W., Overstreet, D.H., Cotman, C.W., Carson, V.G., Churchill, L., Dalglish, F.W. and Vasquez, B.J. (1975): Experimental tests of hypotheses about neurochemical mechanisms underlying behavioral tolerance to the anticholinesterase, diisopropyl fluorophosphate. J. Pharmacol. Exp. Ther., 192, 73-85.

Russell, R.W., Warburton, D.M. and Segal, D.S. (1969): Behavioral tolerance during chronic changes in the cholinergic system. Comm. Behavior Biol., 4, 121-128.

Sakai, M., Fukuyama, H., Sato, K. and Kudoh, I. (2002): Effects of fentanyl on acetylcholine release from hippocampus and righting reflex in rat: An in vivo brain microdialysis study. Masui, 51, 118-123.

Salamone, J.D., Johnson, C.J., McCullough, L.D. and Steinpreis, R.E. (1990): Lateral striatal cholinergic mechanisms involved in oral motor activities in the rat. Psychopharmacology, 102, 529534.

Schwab, C., Bruckner, G., Rothe, T., Castellano, C. and Oliverio, A. (1992): Autoradiography of muscarinic cholinergic receptors in cortical and subcortical brain regions of C57BL/6 and DBA/ 2 mice. Neurochem. Res., 17, 1057-1062.

Shapovalova, K.B. (2002): Muscarinic receptors of the neostriatum-their role in controlling operant behavior in dogs. Neurosci. Behav. Physiol., 32, 389-399.

Sivam, S.P., Nabeshima, T., Lim, D.K., Hoskins, B. and Ho, I.K. (1983): Diisopropylfluorophosphate and GABA synaptic function: Effect on levels, enzymes, release and uptake in the rat striatum. Res. Commun. Chem. Pathol. Pharmacol., 42, 51-60.

Smith, A.D. and Bolam, J.P. (1990): The neural net- work of the basal ganglia as revealed by the study of synaptic connections of identified neurones. Trends Neurosci., 13, 259-265.

Smolen, A., Smolen, T.N., Wehner, J.M. and Collins, A.C. (1985): Genetically determined differences in acute responses to diisopropylfluorophosphate. Pharmacol. Biochem. Behav., 22, 623630.

Smolen, T.N., Smolen, A. and Collins, A.C. (1986): Dissociation of decreased numbers of muscarinic receptors from tolerance to DFP. Pharmacol. Biochem. Behav., 25, 1293-1301.

Stewart, B.R., Jenner, P. and Marsden, C.D. (1989): Assessment of the muscarinic receptor subtype involved in the mediation of pilocarpineinduced purposeless chewing behaviour. Psychopharmacology, 97, 228-234.

Taguchi, K., Hagiwara, Y., Suzuki, Y. and Kubo, T. (1993): Effects of morphine on release of acetylcholine in the rat striatum: An in vivo microdialysis study. Naunyn Schmiedebergs Arch. Pharmacol., 347, 9-13.

Taguchi, K., Kato, M., Kikuta, J., Abe, K., Chikuma, T., Utsunomiya, I. and Miyatake, T. (1999): The effects of morphine-induced increases in extracellular acetylcholine levels in the rostral ventrolateral medulla of rat. J. Pharmacol. Exp. Ther., 289, 1539-1544.

Thomsen, R.H. and Wilson, D.F. (1988): Neuromuscular transmission changes associated with tolerance development after chronic exposure to diisopropylfluorophosphate. J. Pharmacol. Exp. Ther., 247, 635-639.

Tien, L.T., Fan, L.W., Ma, T., Loh, H.H. and Ho, I.K. (2004a): Increased diisopropylfluorophosphate (DFP)-induced toxicity in $\mu$-opioid receptor knockout mice. J. Neuroscience Res., 78, 259267.

Tien, L.T., Fan, L.W., Sogawa, C., Ma, T., Loh, H.H. and Ho, I.K. (2004b): Changes in acetylcholinesterase activity and muscarinic receptor bindings in $\mu$-opioid receptor knockout mice. Brain Res. Mol. Brain Res., 126, 38-44.

van der Zee, E.A. and Luiten, P.G. (1999): Muscarinic acetylcholine receptors in the hippocampus, neocortex and amygdala: A review of immunocytochemical localization in relation to learning and memory. Prog. Neurobiol., 58, 409-471.

Wainer, B.H., Bolam, J.P., Freund, T.F., Henderson, Z., Totterdell, S. and Smith, A.D. (1984): Cholinergic synapses in the rat brain: A correlated light 
DFP in $\mu$-opioid receptor knockout mice.

and electron microscopic immunohistochemical study employing a monoclonal antibody against choline acetyltransferase. Brain Res., 308, 69-76.

Wess, J., Duttaroy, A., Gomeza, J., Zhang, W., Yamada, M., Felder, C.C., Bernardini, N. and Reeh, P.W. (2003): Muscarinic receptor sub- types mediating central and peripheral antinociception studied with muscarinic receptor knockout mice. Life Sci., 72, 2047-2054.

Woolf, N.J. (1991): Cholinergic systems in mammalian brain and spinal cord. Prog. Neurobiol., 37, 475-524. 